\title{
Case study of microarthropod communities to assess soil quality in different managed vineyards
}

\author{
E. Gagnarli ${ }^{1}$, D. Goggioli ${ }^{1}$, F. Tarchi ${ }^{1}$, S. Guidi ${ }^{1}$, R. Nannelli ${ }^{1}$, N. Vignozzi ${ }^{1}$, G. Valboa ${ }^{1}$, M. R. Lottero ${ }^{2}$, \\ L. Corino ${ }^{2}$, and S. Simoni ${ }^{1}$ \\ ${ }^{1}$ CRA-ABP, Consiglio per la Ricerca in Agricoltura e l'analisi dell'economia agraria - Research Centre for \\ Agrobiology and Pedology, Firenze, Italy \\ ${ }^{2}$ CRA-ENO, Consiglio per la Ricerca in Agricoltura e l'analisi dell'economia agraria - Research Centre for \\ Oenology, Asti, Italy \\ Correspondence to: E. Gagnarli (elena.gagnarli@entecra.it)
}

Received: 22 October 2014 - Published in SOIL Discuss.: 21 January 2015

Accepted: 13 June 2015 - Published: 14 July 2015

\begin{abstract}
Land use influences the abundance and diversity of soil arthropods. The evaluation of the impact of different management strategies on soil quality is increasingly sought, and the determination of community structures of edaphic fauna can represent an efficient tool. In the area of Langhe (Piedmont, Italy), eight vineyards characterized for physical and chemical properties (soil texture, soil $\mathrm{pH}$, total organic carbon, total nitrogen, calcium carbonate) were selected. We evaluated the effect of two types of crop management, organic and integrated pest management (IPM), on abundance and biodiversity of microarthropods living at the soil surface. Soil sampling was carried out in winter 2011 and spring 2012. All specimens were counted and determined up to the order level. The biodiversity analysis was performed using ecological indexes (taxa richness, dominance, Shannon-Wiener, Buzas and Gibson's evenness, Margalef, equitability, Berger-Parker), and the biological soil quality was assessed with the BSQ-ar index.

The mesofauna abundance was affected by both the type of management and sampling time. On the whole, a higher abundance was in organic vineyards $(N=1981)$ than in IPM ones $(N=1062)$. The analysis performed by ecological indexes showed quite a high level of biodiversity in this environment, particularly in May 2012. Furthermore, the BSQ-ar values registered were similar to those obtained in preserved soils.
\end{abstract}

\section{Introduction}

The functioning of terrestrial ecosystems depends on the relationships between above- and belowground food webs. In particular, the transfer of biotic components of the decomposer subsystem highly affects the relationship between the two components (Kardol et al., 2011; Wardle et al., 2004).

Soil quality characteristics such as stability, resilience to disturbance or stress and biodiversity (van Bruggen and Semenov, 2000) are directly influenced by land use and management practices (DeFries et al., 2004). Assessment of soil quality is a complex issue that depends on the combination of all physical, chemical and biological properties.
The capability of a soil to sustain biological productivity while at the same time maintaining environmental equilibrium cannot be directly measured; however, it can be assessed through indicators based on biological components of soil that need standardization and suitable databases. Compared with forestry, there is generally less agreement about how the relationship between biodiversity and agriculture should be measured. Much of the emphasis - where it occurs at all - is focused on measuring detrimental impacts of agriculture on surrounding habitats (for instance through soil erosion or pollution run-off) rather than looking at biodiversity within agricultural systems (Dudley et al., 2005). The development of agroecological technologies and systems which emphasize the conservation/regeneration of bio- 
diversity, soil, water and other resources is urgently needed to meet the growing array of socioeconomic and environmental challenges (Altieri, 1999; Lavelle, 2000). European policies for sustainable agronomic management have been implemented, but these need to be evaluated for their efficiency (Chikoski et al., 2006; Herzog, 2005).

Several studies have documented the importance of the soil biota for soil quality and vitality (Lavelle et al., 2006), as well as its potential for reflecting anthropogenic disturbances (Paoletti et al., 1991; Van Straalen, 1998). In an agricultural context, the combination of productive goals and sustainable land uses protecting both soil and biodiversity is essential in order to prevent the decline of soil fauna communities (Menta et al., 2011). Enhancing biodiversity in agroecosystems is a key ecological strategy to make sustainable productions.

Farming practices such as ploughing, chemical fertilization and pesticide application can affect soil quality by modifying soil characteristics (Mazzoncini et al., 2010). Therefore, soil quality can be assessed by physical, chemical and microbiological properties of soil together with the abundance and diversity of edaphic fauna (nematodes, Acari, Collembola, Symphyla, Chilopoda, Pauropoda, enchytraeids, earthworms); furthermore, the determination of community structure adds significant information on the soil status (Cole et al., 2006; De Goede and Brussard, 2002; Duelli and Obrist, 2003; Menta et al., 2008; van Straalen, 1998; Yan et al., 2012). In a well-balanced soil, mesofauna is highly biodiversified and occupies all trophic levels within the soil food webs (Ruf et al., 2006). Therefore, the loss of mesofauna diversity is a negative consequence on soil biota, since it is involved in fundamental ecosystem services such as nutrient cyclings (Gardi et al., 2008; Narula et al., 1996). The knowledge of interactions between the different groups of organisms and of mechanisms regulating the soil food web is crucial for assessing the sustainability of land use; however there is a need for further studies (Maraun and Scheu, 2000).

Soil microarthropods, as litter transformers, improve soil quality and affect the soil structural properties (porosity, aeration, infiltration and distribution of organic matter in soil horizons) (Bird et al., 2004; Culliney, 2013). They are concentrated in the litter layers and upper horizons of the soil, and their abundance and distribution are highly dependent on individual tolerance limits to environmental conditions (Chikoski et al., 2006; Faber and Verhoef, 1991). Microarthopods are useful models as they are both taxonomically and ecologically highly diversified; particularly, euedaphic forms are unable to survive abrupt variations due to the disturbances caused, for example, by agricultural cultivation and trampling (Parisi et al., 2005; Menta, 2012).

The literature suggests that organically managed fields contain a greater abundance and diversity of arthropods than conventionally managed fields (Berry et al., 1996; Hole et al., 2005; Pimentel et al., 2005; Reddersen, 1997) and that changing from conventional to organic farming leads to a gradual increase in biodiversity (van Diepeningen et al., 2006).

The aim of this study was to determine the effect of management practices in experimental vineyards, by comparing organic and integrated pest management (IPM), on soil microarthropod community structure and composition before and after treatments. In particular, we hypothesized that organic management may positively affect the abundance (total numbers of individuals), richness (total numbers of taxa (ecomorphological group), diversity and quality indexes of all soil microarthropods as evidenced in the cited studies where organic and conventional managements were compared.

\section{Material and methods}

\subsection{Description of study sites}

The study was carried out in the north-west of Italy, in Piedmont, in the central Tanaro River area (Table 1a). This hilly area is characterized by marls, clays and sands, and is almost entirely devoted to the production of high-quality wines, in particular Barbera. The sampled vineyards are located in a triangle area with $20 \mathrm{~km}$ maximum distance between the vineyards' locations.

According to the georeferenced soil database for Europe, the climatic classification of this area is Mediterranean suboceanic to subcontinental (TM3) (Costantini et al., 2013): this is characterized by a degree of continentality - a rather high temperature difference between summer and winter and a quite regular precipitation pattern - typifying the Po Plain and adjacent low hills as relatively warmer than the other climates of northern Italy. On the whole, although the various microclimates determined by the hills and valleys of the Langhe are influenced by the continental climate of the entire area, the values of average annual temperature of all places lowland (below $300 \mathrm{~m}$ above sea level) are similar (see Table $1 \mathrm{~b}$ ), in the $12-14^{\circ} \mathrm{C}$ range (CREST, 2006). The relatively warm temperature and the rainfall pattern enhance weathering of the soil parent materials; therefore, on stable morphological positions, neogenetic clay can accumulate in depth and Luvisols dominate the soilscape (Costantini et al., 2013). In this area, eight vineyards were selected: four under organic management for ten years and four under IPM. All the vineyards were selected in areas characterized by the similar range of soil texture features (loam, silty clay loam and clay loam) on the basis of previous soil analysis (personal communication by farms' owners and CRA-ENO personnel, 2010). Furthermore, other chemical/physical properties were determined (Table 2). The considered vineyards were distant from each other by a few kilometres and were similar with regard to major physiographic characteristics (slope, orientation, approximate size, soil type). The organic vineyards selected were cultivated without herbicide and synthetic pesticides; they were treated with tribasic copper sulfate $(15.2 \%)$, pure sulfur (wettable powder). Sulfur (powder) 
Table 1. (a) Description of vineyard sampling sites. (b) Yearly mean temperature and rain registered in the three vineyard sites.

\begin{tabular}{|c|c|c|c|c|}
\hline $\begin{array}{l}\text { (a) Sampling site (farm/ } \\
\text { vineyard, site, province) }\end{array}$ & Abbreviation & $\begin{array}{l}\text { GPS } \\
\text { coordinates }\end{array}$ & $\begin{array}{l}\text { Vine } \\
\text { variety }\end{array}$ & $\begin{array}{l}\text { Agricultural } \\
\text { managemen }\end{array}$ \\
\hline $\begin{array}{l}\text { Villa Achille, Costigliole } \\
\text { d'Asti (Asti) }\end{array}$ & CSA_o1 & $\begin{array}{l}44^{\circ} 47^{\prime} 21^{\prime \prime} \mathrm{N} \\
8^{\circ} 9^{\prime} 51^{\prime \prime} \mathrm{E}\end{array}$ & Nebbiolo & organic \\
\hline $\begin{array}{l}\text { Villa Achille, Costigliole } \\
\text { d'Asti (Asti) }\end{array}$ & CSA_o2 & $\begin{array}{l}44^{\circ} 47^{\prime} 22^{\prime \prime} \mathrm{N} \\
8^{\circ} 9^{\prime} 53^{\prime \prime} \mathrm{E}\end{array}$ & Nebbiolo & organic \\
\hline $\begin{array}{l}\text { Vigna Bricco, Costigliole } \\
\text { d'Asti (Asti) }\end{array}$ & CSA_o3 & $\begin{array}{l}44^{\circ} 47^{\prime} 12^{\prime \prime} \mathrm{N} \\
8^{\circ} 11^{\prime} 12^{\prime \prime} \mathrm{E}\end{array}$ & Barbera & organic \\
\hline $\begin{array}{l}\text { Isola Villa, Mongardino } \\
\text { (Asti) }\end{array}$ & CSA_04 & $\begin{array}{l}44^{\circ} 49^{\prime} 59^{\prime \prime} \mathrm{N} \\
8^{\circ} 11^{\prime} 24^{\prime \prime} \mathrm{E}\end{array}$ & Barbera & organic \\
\hline $\begin{array}{l}\text { Az. Piana, Castelboglione } \\
\text { (Asti) }\end{array}$ & CSB_i1 & $\begin{array}{l}44^{\circ} 43^{\prime} 24^{\prime \prime} \mathrm{N} \\
8^{\circ} 22^{\prime} 39^{\prime \prime} \mathrm{E}\end{array}$ & Barbera & IPM \\
\hline $\begin{array}{l}\text { Az. Piana, Castelboglione } \\
\text { (Asti) }\end{array}$ & CSB_i2 & $\begin{array}{l}44^{\circ} 43^{\prime} 25^{\prime \prime} \mathrm{N} \\
8^{\circ} 22^{\prime} 38^{\prime \prime} \mathrm{E}\end{array}$ & Barbera & IPM \\
\hline $\begin{array}{l}\text { Cavallotto, Castiglion } \\
\text { Falletto, (Cuneo) }\end{array}$ & CSF_i3 & $\begin{array}{l}44^{\circ} 37^{\prime} 14^{\prime \prime} \mathrm{N} \\
7^{\circ} 58^{\prime} 40^{\prime \prime} \mathrm{E}\end{array}$ & Barbera & IPM \\
\hline $\begin{array}{l}\text { Cavallotto, Castiglion } \\
\text { Falletto (Cuneo) }\end{array}$ & CSF_i4 & $\begin{array}{l}44^{\circ} 37^{\prime} 17^{\prime \prime} \mathrm{N}, \\
7^{\circ} 58^{\prime} 40^{\prime \prime} \mathrm{E}\end{array}$ & Nebbiolo & IPM \\
\hline
\end{tabular}

\begin{tabular}{lrrrr}
\hline \hline (b) & & $\begin{array}{r}\text { Costigliole d'Asti } \\
\text { (CSA) }\end{array}$ & $\begin{array}{r}\text { Castelboglione } \\
\text { (CSB) }\end{array}$ & $\begin{array}{r}\text { Castiglion Falletto } \\
\text { (CSF) }\end{array}$ \\
\hline Temperature $\left({ }^{\circ} \mathrm{C}\right)$ & 2010 & 12.5 & 12.4 & 12.2 \\
& 2011 & 13.7 & 14.4 & 13.9 \\
& 2012 & 13.3 & 11.6 & 13.8 \\
\hline Cumulative rain $(\mathrm{mm})$ & 2010 & 881.7 & 715.8 & 757.0 \\
& 2011 & 540.0 & 733.4 & 506.0 \\
& 2012 & 589.0 & 448.8 & 543.2 \\
\hline
\end{tabular}

Table 2. Soil physical and chemical parameters of the investigated vineyard sites (March 2011).

\begin{tabular}{llrrrrr}
\hline & $\begin{array}{l}\text { Textural class } \\
\text { (USDA, 1993) }\end{array}$ & $\begin{array}{r}\text { TOC } \\
(\%)\end{array}$ & $\begin{array}{r}\text { TN } \\
(\%)\end{array}$ & $\begin{array}{c}\text { C / N } \\
\text { pH }\end{array}$ & $\begin{array}{r}\mathrm{CaCO}_{3} \\
(\%)\end{array}$ \\
\hline CSA_01 & loam (L) & 0.95 & 0.10 & 9.5 & 7.4 & 30.5 \\
CSA_02 & silty clay loam (SCL) & 1.12 & 0.12 & 9.7 & 7.9 & 25.5 \\
CSA_03 & clay loam (CL) & 1.90 & 0.19 & 10.3 & 7.9 & 24.1 \\
CSA_04 & silty clay loam (SCL) & 0.96 & 0.10 & 9.2 & 7.9 & 12.9 \\
CSB_i1 & silty clay loam (SCL) & 1.08 & 0.13 & 8.7 & 7.9 & 26.7 \\
CSB_i2 & silty clay loam (SCL) & 0.74 & 0.10 & 7.5 & 7.9 & 29.1 \\
CSF_i3 & clay loam (CL) & 0.82 & 0.10 & 8.2 & 7.9 & 26.8 \\
CSF_i4 & loam (L) & 0.94 & 0.10 & 9.0 & 7.9 & 52.2 \\
\hline
\end{tabular}

was widely used to control powdery mildew on grapes. In each organic farm, agronomic practices used were no-tillage, yearly spadework intra-row and mowing of grass.

IPM were treated with anti-downy mildew fungicides such as metiram (three times), metiram + systemic (three times), copper hydroxide and Bordeaux mixture (copper sulfate and lime) (four times); with anti-powdery mildew fungicides including sulfur (powder), tebuconazole (twice) and wettable powder sulfur; with antibotrytis fungicides such as a formulation with cyprodinil (37.5\%) and fludioxonil (25\%); and with insecticides such as chlorpyrifos-methil (twice) and pyrethroids. On soil along the row, glyphosate was used as a herbicide (once a year); in 2012, the second year of study, no herbicide was applied in CSF_i3 and CSF_i4. Agricultural machinery and minimum tillage were also implemented.

\subsection{Soil sampling and processing}

Soil samples for the study of microarthropods were carried out in late winter 2011 and spring 2012. In each site, one plot $(10 \mathrm{~m} \times 25 \mathrm{~m})$ was selected in the inner area of the vineyard to minimize edge effects. Three samples per plot were collected along a linear transect between rows at about $40 \mathrm{~cm}$ from the plant. Sample cores were obtained using a drill corer $(3 \mathrm{~cm}$ diameter, $30 \mathrm{~cm}$ depth). Close to these samples for the study of mesofauna, equivalent soil cores were taken for chemical analysis in 2011. The samples for microarthropods extraction were air-dried and then sieved ( $2 \mathrm{~mm}$ mesh size) in Berlese-Tullgren funnels. All specimens were counted and determined up to the order level.

The samples collected for determination of abiotic parameters were homogenized for each vineyard. Soil texture was determined by the X-ray attenuation method according to the procedure described by Andrenelli et al. (2013), using a Micromeritics SediGraph apparatus. The procedure provides pipette-equivalent results. Soil $\mathrm{pH}$ was determined potentio- 
metrically in a $1: 2.5$ soil : water suspension. Soil total organic carbon (TOC) and total nitrogen (TN) were determined by dry combustion, using a Thermo Flash $2000 \mathrm{CN}$ analyser. Each soil sample was analysed two times separately: 60$70 \mathrm{mg}$ of soil was weighed into Sn capsules and analysed for total C (organic + mineral C) and total $\mathrm{N}$ contents; $20-30 \mathrm{mg}$ of soil was weighed into $\mathrm{Ag}$ capsules, treated with $10 \% \mathrm{HCl}$ until complete removal of carbonates and then analysed for total $\mathrm{C}$ content (organic $\mathrm{C}$ ). The difference in the $\mathrm{C}$ content between the untreated and the $\mathrm{HCl}$-treated soil was used to assess the total equivalent $\mathrm{CaCO}_{3}$ content (Sequi and De Nobili, 2000).

\subsection{Data and biodiversity analysis}

The influence of management and soil sampling was evaluated on the density of mesofauna by means of analysis of variance (ANOVA). In the present study, the biological soil quality was defined through qualitative and quantitative indices. The ecological quali-quantitative indices, calculated for each management in spring and autumn samples, were the following (see Harper, 1999; Krebs, 1989): taxa richness $(S)$, abundance $(N)$ and dominance $(D)$ (Dominance $=1-$ Simpson index), ranging from 0 (all taxa are equally present) to 1 (one taxon is completely dominant in the community); $H$ : Shannon-Wiener index, taking into account the number of individuals as well as number of taxa, varying from 0 for communities with only a single taxon to high values for communities with many taxa, each with few individuals; $E$ : Buzas and Gibson's evenness, measuring the evenness in the communities; $I_{\text {Marg: }}$ : Margalef index, measuring number of species present for a given number of individuals; $J$ : equitability index, measuring the evenness with which individuals are divided among the taxa present; and $d$ : Berger-Parker index, dominance indicating the number of individuals in the dominant taxon.

Biological quality of soil was evaluated by the BSQ-ar index (Parisi, 2001). The BSQ-ar index is based on direct correlation between the quality of soil and the number of microarthropods adapted to the soil habitat. It uses the biological form approach to separate the mesofauna specimens into morphological classes according to their levels of adaptation to the soil environment. Each form is ecomorphologically scored (EMI: eco-morphological index), ranging from 1 to 20 , on the basis of its edaphic adaptation level. The sum of EMIs gives the global value of BSQ-ar index. The biological soil quality was characterized on the basis of D'Avino (2002) classification and the values were compared by the MannWhitney test.

The statistics concerning the calculation and comparisons of the biodiversity indexes were obtained using the program PAST (2013) (Hammer et al., 2001). All other statistical analyses were performed using the statistical program SPSS 13.0 (SPSS, 2004).
A) 15 November. 2010 - 15 March, 2011
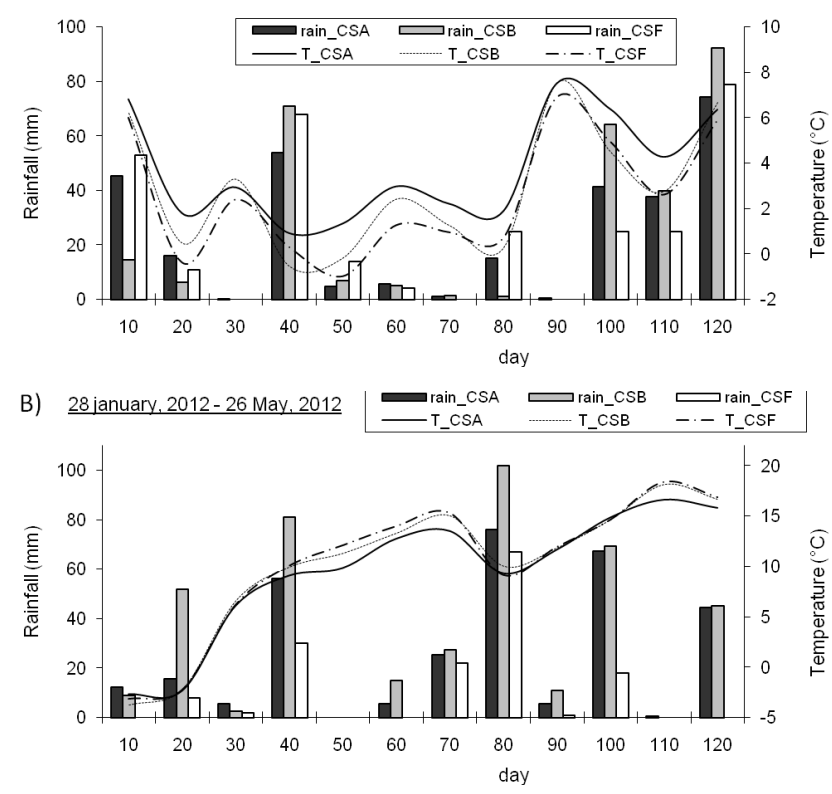

Figure 1. Temperature (lines) and rainfall (bars) measured in the three vineyard sites (CSA, CSB, CSF) for 120 days before the soil samplings in 2010-2011 (a) and 2012 (b).

\section{Results}

\subsection{Soil microarthropod abundance}

The climate data for air temperature and rainfall registered in the three locations for 120 days before the samplings are reported in Fig. 1. During the considered periods, the daily mean temperatures were quite similar in the different localities with values around $3{ }^{\circ} \mathrm{C}$ in the period December 2010-March 2011 and around $10^{\circ} \mathrm{C}$ in the period January-May 2012. Regarding rainfall, on the whole, very similar values were registered in 2010-2011, with a cumulative rainfall of about $300 \mathrm{~mm}$; in 2012, the cumulative rainfall registered was less homogeneous, and the highest amount was registered in the CSB area.

The soil characteristics of studied sites are reported in Table 2. The different vineyard soils had quite homogeneous texture, ranging from medium (loam) to moderately fine (clay loam and silty clay loam). Soil TOC content was generally medium, scarce in $\mathrm{CSB}_{-} \mathrm{i} 2$ and $\mathrm{CSF}$ _i3, and high in CSA_03. TN content was the highest in CSA_o3. Soil pH ranged from slightly to moderately alkaline. Total $\mathrm{CaCO}_{3}$ content showed wide variability, from extremely calcareous (CSF_i4) to weakly calcareous (CSA_o4) (Costantini, 2009).

On the whole, the abundance of microarthropods was higher in the organic vineyards than in IPM ones, with a ratio of about $2: 1$, and the mesofauna density was considerably affected by both sampling time $\left(F_{1,45}=15.02 ; P=0.000\right)$ and management $\left(F_{1,45}=11.01 ; P=0.002\right)$. The density of microarthropods registered in May 2012 was higher than that 
Table 3. Community structure of the soil microarthropods $(N)$ (biological forms as morphotypes adapted to soil) (Parisi et al., 2005) at different sampling times and in the eight vineyard sites.

\begin{tabular}{|c|c|c|c|c|c|c|c|c|c|c|c|}
\hline $\begin{array}{l}\text { March } \\
2011\end{array}$ & CSA_o1 & CSA_o2 & CSA_o3 & CSA_o4 & Organic & CSB_i1 & CSB_i2 & CSF_i3 & CSF_i4 & IPM & $\begin{array}{r}\text { Total } \\
\text { abundance } \\
(N)\end{array}$ \\
\hline Acari & 98 & 61 & 115 & 85 & 359 & 32 & 22 & 38 & 28 & 120 & 479 \\
\hline Collembola & 63 & 39 & 33 & 84 & 219 & 51 & 6 & 28 & 7 & 92 & 311 \\
\hline Chilopoda & & 1 & 1 & 1 & 3 & 1 & & & & 1 & 4 \\
\hline Coleoptera & & 2 & 1 & & 3 & & & & 1 & 1 & 4 \\
\hline Diplura & & & & 1 & 1 & & & & & 0 & 1 \\
\hline Diptera larvae & 2 & 1 & 4 & 1 & 8 & & & 2 & 1 & 3 & 11 \\
\hline Diptera & 1 & 3 & 4 & 2 & 10 & 5 & 2 & 1 & 8 & 16 & 26 \\
\hline Rhynchota & & & & 1 & 1 & & & & & 0 & 1 \\
\hline Hymenoptera & & & & 44 & 44 & & 23 & & & 23 & 67 \\
\hline Coleoptera larvae & 7 & & 3 & 5 & 15 & 1 & 3 & 1 & & 5 & 20 \\
\hline Homoptera & 1 & & & & 1 & & & & & 0 & 1 \\
\hline Pauropoda & & 7 & 1 & 5 & 13 & & & & & 0 & 13 \\
\hline Protura & 1 & 4 & 4 & 2 & 11 & & & & & 0 & 11 \\
\hline Pseudoscorpionida & & 1 & & 1 & 2 & & & & & 0 & 2 \\
\hline Symphyla & 3 & 8 & & 13 & 24 & 1 & & & 3 & 4 & 33 \\
\hline Thysanoptera & 1 & 1 & & 3 & 5 & & & 1 & & 1 & 6 \\
\hline Total $(N)$ & 177 & 128 & 166 & 248 & 719 & 91 & 56 & 71 & 48 & 266 & 985 \\
\hline $\begin{array}{l}\text { May } \\
2012\end{array}$ & CSA_o1 & CSA_o2 & CSA_03 & CSA_o4 & Organic & CSB_i1 & CSB_i2 & CSB_i3 & CSB_i4 & IPM & $\begin{array}{r}\text { Total } \\
\text { abundance } \\
(N)\end{array}$ \\
\hline Acari & 103 & 133 & 320 & 183 & 739 & 124 & 103 & 133 & 79 & 439 & 1178 \\
\hline Collembola & 46 & 102 & 199 & 63 & 410 & 67 & 30 & 93 & 44 & 234 & 644 \\
\hline Chilopoda & & & & & 0 & & & 2 & 2 & 4 & 4 \\
\hline Coleoptera & & & 1 & & 1 & & & 1 & 3 & 4 & 5 \\
\hline Diplopoda & & & & 1 & 1 & 1 & & & & 1 & 2 \\
\hline Diplura & & 3 & & 4 & 7 & & & & 3 & 3 & 10 \\
\hline Diptera larvae & & & 2 & 2 & 4 & & & & & 0 & 4 \\
\hline Diptera & & & 11 & 2 & 13 & & & & & 0 & 13 \\
\hline Rhynchota & & & 1 & 2 & 3 & 3 & 24 & 10 & & 37 & 40 \\
\hline Hymenoptera & 2 & & 11 & 3 & 16 & 1 & 12 & & 1 & 14 & 30 \\
\hline Isopoda & & & & 1 & 1 & 1 & & & & 1 & 2 \\
\hline Coleoptera larvae & & & 9 & 7 & 16 & & & 39 & 2 & 41 & 57 \\
\hline Homoptera & & & 5 & & 5 & & 1 & & & 1 & 6 \\
\hline Pauropoda & & 6 & 5 & 3 & 14 & 4 & & 2 & 1 & 7 & 21 \\
\hline Protura & & & & & 0 & & & & 1 & 1 & 1 \\
\hline Pseudoscorpionida & & 2 & & & 2 & & 1 & & & 1 & 3 \\
\hline Psocoptera & & & 2 & & 2 & 1 & & & & 1 & 3 \\
\hline Symphyla & 1 & 7 & 4 & 10 & 22 & 3 & & & 2 & 5 & 27 \\
\hline Thysanoptera & 3 & 2 & 1 & & 6 & 1 & & 1 & & 2 & 8 \\
\hline Total $(N)$ & 155 & 255 & 571 & 281 & 1262 & 206 & 171 & 281 & 138 & 796 & 2058 \\
\hline
\end{tabular}

registered in March 2011 ( $t$ test $=3.51, d f=46, P=0.001$ ). Overall, the organically managed vineyards had a higher density than the IPM ones ( $t$ test $=2.91, d f=46, P=0.006$ ).

Figure 2 shows the total soil microarthropod density registered in the different samplings. In 2011, a higher density was registered in the organic vineyards $(t$ test $=4.38$, $d f=22, P=0.000)$. In 2012, there was no difference in density ( $t$ test $=1.79, d f=22, P=0.09)$.

The community structure of the soil microarthropods in the different seasons is reported in Table 3. The distribution of the three main animal groups (Acari, Collembola, other arthropods) did not show any substantial difference depending on management. The mites represented about $50 \%$ of the total arthropodofauna recorded, collembolans about $30 \%$, and other microarthropods about $20 \%$. The group of the other arthropods was represented by epiedaphic (Rincota, Thysanoptera, Diptera, Psocoptera, Blattodea), hemiedaphic (Hymenoptera, holometabolous larvae, Diptera larvae, Geophilomorpha, Julida, Isopoda, Homoptera) and euedaphic forms (Symphyla, Pauropoda, Pseudoscorpionida, Coleoptera, Protura, Diplura). 


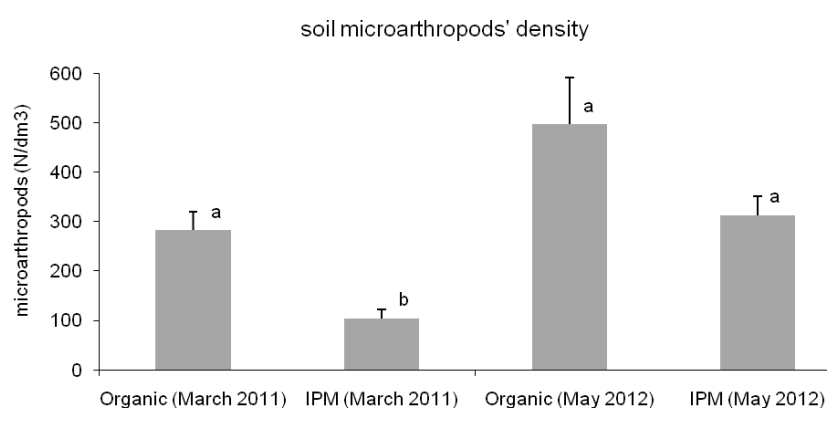

Figure 2. Density of soil microarthropods measured as means $( \pm \mathrm{SE})$ of individuals, $(N) / 1 \mathrm{~d} \mathrm{~m}^{3}$ soil volume, determined for management and data sampling. Within the year, different letters indicate significance in the values' comparison ( $t$ test, $P<0.05$ ).

\subsection{Soil microarthropod biodiversity}

The biodiversity indexes and their comparisons are reported in Table 4. In March 2011, the taxa richness was higher in the organically managed vineyards; the Margalef index denoted a higher variation in soil samples from the organic vineyards, while a higher evenness $(E=0.39)$ was registered in the IPM vineyards. In May 2012, the same numbers of taxa were registered in organic and IPM vineyards but dominance ( $D=0.45)$ was higher in organic ones: this was due to the presence of one or two groups mainly from the community of arthropods; a different and quite homogeneous distribution in the structure of population from IPM vineyards determined higher values of Shannon-Wiener $(H=1.27)$ and equitability index $(J=0.44)$.

The BSQ-ar index was higher in the organic than in the IPM vineyards in March 2011 (Mann-Whitney, $U=1332$ $P=0.000$ ) (Table 5); there was no difference in May 2012 (Mann-Whitney, $U=2721 P=0.6$ ).

\section{Discussion and conclusions}

On the whole, several studies report about comparison in biodiversity between organic and conventional fields/crops by indicating a greater abundance and diversity of arthropods in organic ones (e.g. Hole et al., 2005; Kromp, 1990; Liebig and Doran, 1999; Reddersen, 1997). Less data and evidence are available in the evaluation of the artropod biodiversity to compare organic and IPM managements (Landi et al., 2014; Todd et al., 2015). The organic and integrated systems showed higher soil quality and potentially lower negative environmental impact than the conventional system (Mazzoncini et al., 2010; Reganold et al., 2001).

In the present study case, in vineyards, the effect of organic and IPM managements on soil quality was evaluated through the characterization of the entire microarthropod community living on soil surface. The total abundance and biodiversity of microarthropods were higher in the organically managed vineyards than the IPM ones only in March 2011.
Table 4. Taxa richness $(S)$, abundance $(N)$, and biodiversity index values ( $D$ : dominance; $H$ : Shannon-Wiener; $E$ : Buzas and Gibson's evenness; $I_{\text {Marg }}$ : Margalef; $J$ : equitability; $d$ : Berger-Parker) for each management type in spring and autumn samples.

\begin{tabular}{lrrrrrrrr}
\hline & \multicolumn{3}{c}{ March 2011 } & & \multicolumn{3}{c}{ May 2012 } \\
\cline { 2 - 5 } \cline { 6 - 8 } & Organic & IPM & Boot $p($ eq $)$ & & Organic & IPM & Boot $p($ eq $)$ \\
\hline$S$ & 16 & 10 & $0.02^{\mathrm{a}}$ & & 17 & 17 & 1 \\
$N$ & 719 & 266 & 0 & & 1262 & 796 & 0 \\
$D$ & 0.35 & 0.34 & 0.58 & & 0.45 & 0.40 & $<0.01^{\mathrm{b}}$ \\
$H$ & 1.44 & 1.36 & 0.33 & & 1.10 & 1.27 & $<0.01^{\mathrm{b}}$ \\
$E$ & 0.26 & 0.39 & $0.04^{*}$ & & 0.18 & 0.21 & 0.22 \\
$I_{\text {Marg }}$ & 2.28 & 1.62 & $0.02^{\mathrm{a}}$ & & 2.24 & 2.34 & 0.49 \\
$J$ & 0.52 & 0.59 & 0.13 & & 0.39 & 0.44 & $0.01^{\mathrm{b}}$ \\
$d$ & 0.49 & 0.45 & 0.15 & & 0.59 & 0.55 & 0.13 \\
\hline
\end{tabular}

a $P<0.05 ;{ }^{\text {b }} P<0.01$.

Some factors may have contributed to this evidence. Compared to the organic management, which was based on notillage, allowing natural grass to cover the vineyard floor over the whole year, IPM may have resulted in higher soil disturbance due to the tillage treatment performed at the beginning of winter, which can explain the lower collembolan population (Heisler, 1991).

The treatments applied on vine plants in the different managed vineyards did not seem to affect the soil mesofauna as registered by Scalercio et al. (2009) on olive groves. Conversely, the suppression of the herbicide (glyphosate formulations) application, in IPM fields in 2012, appeared to benefit the organisms living in the topsoil; this was observed by Gomez and Sagardoy (1985) and by Renaud et al. (2004) on springtails.

In addition, the difference registered in 2011 and 2012 in the total abundance could be affected by climatic data registered in the previous sampling periods and natural seasonal fluctuations in soil microarthropods (Culliney, 2013; Narula et al., 1996). In accordance with other studies, the number of springtails, in 2012, increased after rainfall, finding an optimal habitat (Badejo et al., 1998; Costantini et al., 2015; Schaefer, 1995).

In the first half of February 2012, Piedmont was affected by an exceptional cold spell, while an average deficit of $8 \%$ rainfall was observed (ARPA Piemonte, 2012).

Concerning the biodiversity analysis, the higher dominance in May 2012 in organic vineyards than IPM ones was due to mite and springtail populations: these groups represented $91 \%$ of the total microarthropods collected. On the whole, within Acari, the oribatid mites were the most represented with a ratio of about $2: 1$ (oribatids in organic vs. oribatids in IPM). This evidence seems to be in agreement with those registered by several authors that consider the oribatid mites as a good bioindicator as their community structure can be significantly affected by several levels of disturbance (Behan-Pelletier, 1999; Caruso and Migliorini, 2006). 


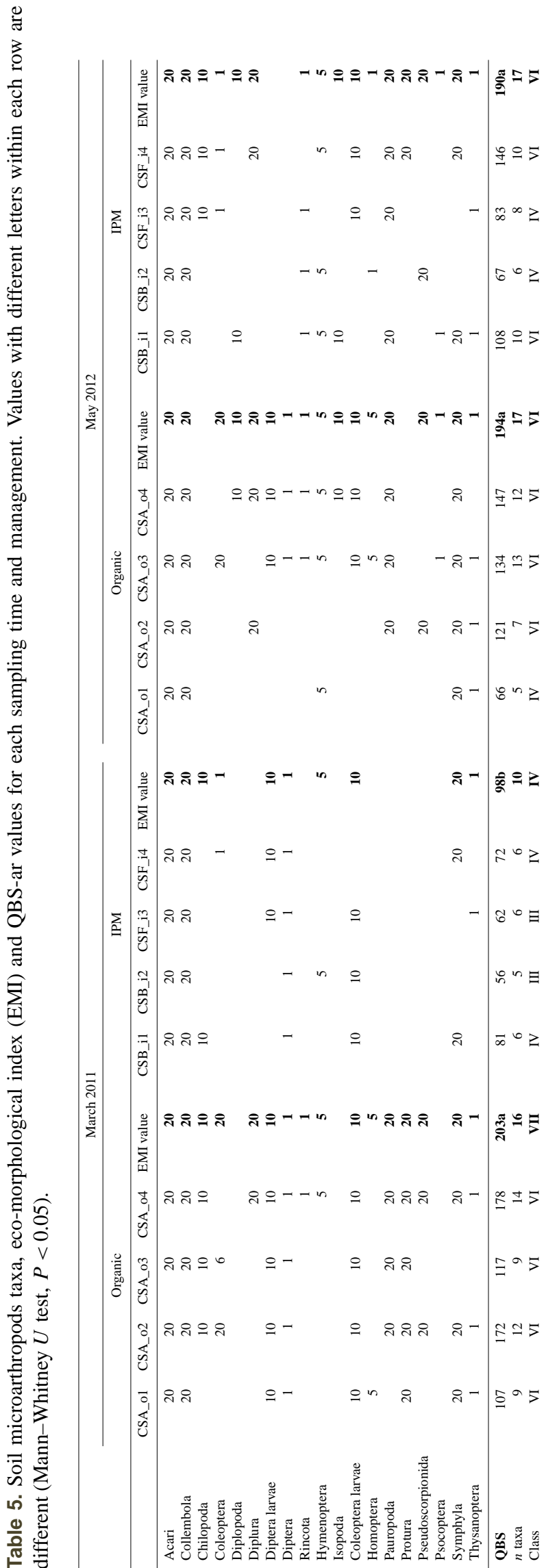

The biodiversity indexes registered in 2011, in particular the Margalef index, were affected by the difference in taxa richness. In organic vineyards, conspicuous presence of euedaphic groups was registered such as pseudoscorpions, Protura, Diplura, springtails, mites and small myriapods (Pauropoda and Symphyla). In 2012, the same number of taxa richness values was measured in the different management. However, the relative frequency in each taxon determined higher values in Shannon-Wiener and equitability indexes in IPM vineyards.

The BSQ-ar values were consistent with the total microarthropod abundance.

The biological quality of the soil was very high in the organic vineyards of Costigliole d'Asti area. These soils can be ascribed to high biological classes (VI), similar to those registered in undisturbed and forestal soils (Parisi et al., 2005). Miani et al. (2005) found similar evidence, with BSQ-ar values higher (about $20 \%$ ) in organic vineyards than the values registered in conventionally managed ones.

In this case study, on the yearly basis, the IPM strategy seemed to affect the soil biota; however, on a short timescale, high BSQ-ar values were registered by denoting that these soils are still resilient and show quick microarthropod recolonization. Biodiversity plays a fundamental role in the capacity of the soil to recover its initial situation after a natural or human perturbation (Spratt, 1997). The presence of some euedaphic groups (Protura, Diplura and Pauropoda), even if less affecting the soil processes (Eisenbeis and Wichard, 1987), is highly responsive to stress conditions and can be relevant for the purpose of biomonitoring (Parisi et al., 2005).

The BSQ-ar allowed for different situations to be compared and for guidance to be provided for the interpretation of the impact management. At the same time, it must be emphasized that, if a study aim is qualitatively focused on highlighting the presence of key species (i.e. sensitive to agricultural processing/works) well adapted to soil habitat, it is highly advisable to evaluate the euedaphic forms present in a deeper sampling range or to study the vertical migration of microarthropods.

By perspective, attention should be moved from the monitoring method to evaluate to which extent the processes determined by microarthropods can affect a plant's physiological and productive status. The effects of soil biodiversity on vegetation dynamics operate through a variety of biotic interactions, among which are the changing interactions between plants and their below- and above-ground multitrophic communities (Bardgett and van der Putten, 2014).

This kind of evidence can be integrated in the microarthropod studies addressing spatial and temporal partitioning, population dynamics, and taxon-specific or functional groups. As soil arthropods include a wide range of taxa with diverse patterns of response to different kinds of anthropogenic perturbations (Decaëns et al., 2006), may provide a wider view of soil quality if they are combined with other 
parameters (e.g. soil physico-chemical conditions, bioavailability).

Further research is needed to establish more quantitative relationships between specific groups, especially among arthropods, to better understand the roles of soil fauna in $\mathrm{C}$ and $\mathrm{N}$ cycles and crucially developing such ecologicaleconomic links to assess the effects of agricultural systems on specific, measurable properties that are important indicators of sustainability.

Acknowledgements. The authors would like to thank the following vineyard farms for their receptiveness and kindness: Az. Agr. Corino Lorenzo, Costigliole d'Asti (Asti); Az. Agr. Piana Antonio, Castelboglione (Asti); and Tenuta Vitivinicola Bricco Boschis, Cavallotto, Castiglione Falletto (Cuneo).

Edited by: S. Mocali

\section{References}

Altieri, M. A.: The ecological role of biodiversity in agroecosystems, Agr. Ecosyst. Environ., 74, 19-31, 1999.

Andrenelli, M. C., Fiori, V., and Pellegrini, S.: Soil particle-size analysis up to 250 micron by X-ray granulometer: device set-up and regressions for data conversion into pipette-equivalent values, Geoderma, 192, 380-393, 2013.

ARPA (Agenzia Regionale per la Protezione Ambientale) Piemonte: Il clima in Piemonte nel 2011, available at: http://www.arpa.piemonte.it/approfondimenti/temi-ambientali/ meteorologia-e-clima/clima/clima2012.pdf (last access: 16 January 2012), 2011.

Badejo, M. A., Nathaniol, T. I., and Tian, G.: Abundance of springtails (Collembola) under four agroforestry tree species with contrasting litter quality, Biological Fertility of Soils, 27, 15-20, 1998.

Bardgett, R. D. and van der Putten, W. H.: Belowground biodiversity and ecosystem functioning, Nature, 515, 505-511, 2014.

Behan-Pelletier, V. M.: Oribatid mites in agroecosystems: role for bioindication, Agr. Ecosyst. Environ., 74, 411-423, 1999.

Berry, N. A., Wratten, S. D., McErlich, A., and Frampton, C.: Abundance and diversity of beneficial arthropods in conventional and organic carrot crops in New Zealand, New Zea. J. Crop Hort., 24, 307-313, 1996.

Bird, S. B., Coulson, R. N. and Fisher, R. F.: Change in soil and litter arthropods abun-dance following tree harvesting and site preparation in a loblolly pine (Pinus taeda L.) plantation, Forest. Ecol. Manag., 202, 195-208, 2004.

Caruso, T. and Migliorini, M.: Microarthropod communities under human disturbance: is taxonomic aggregation a valuable tool for detecting multivariate change? Evidence from Mediterranean soil oribatid coenoses, Acta Oecol., 30, 46-53, 2006.

Chikoski, J. M., Ferguson, S. H., and Meyer, L.: Effects of water addition on soil arthropods and soil characteristics in a precipitation-limited environment, Acta Oecol., 30, 203-211, 2006.

Cole, L., Bradford M. A., Shaw, P. J. A., and Bardgett, R. D.: The abundance, richness and functional role of soil meso- and macro- fauna in temperate grassland - A case study, Appl. Soil Ecol., 33, 186-198, 2006.

Costantini, E. A. C.: Appendix: Soil Properties and Qualities, in: Manual of methods for soil and land evaluation, edited by: Costantini, E. A. C., Science Publishers, Enfield, NH, USA, 529539, 2009.

Costantini, E. A. C. and Dazzi, C. (Eds.): The Soils of Italy, World Soils Book Series, doi:10.1007/978-94-007-5642-7_2, Springer Science \& Business Media Dordrecht, 2013.

Costantini, E. A. C., Agnelli, A. E., Fabiani, A., Gagnarli, E., Mocali, S., Priori, S., Simoni, S., and Valboa, G.: Short-term recovery of soil physical, chemical, micro- and mesobiological functions in a new vineyard under organic farming, SOIL, 1, 443457, doi:10.5194/soil-1-443-2015, 2015.

CREST (Centro Ricerche in Ecologia e Scienze del Territorio): Elementi climatici del Piemonte, Report on line, available at: http: //www.crestsnc.it/divulgazione/media/clima-piemonte.pdf (last access: 26 September 2008), 2006.

Culliney, T. W.: Role of Arthropods in Maintaining Soil Fertility, Agriculture, 3, 629-659, 2013.

D'Avino, L.: Esposizione del metodo di Vittorio Parisi per la valutazione della Qualità Biologica del Suolo (QBS) e proposta di standardizzazione delle procedure, CD ROM, Museo di Storia Naturale di Parma, Italy, 2002.

Decaëns, T., Jiménez, J. J., Gioia, C., Measey, G. J., and Lavelle, P.: The values of soil animals for conservation biology, Eur. J. Soil Biol., 42, 23-38, 2006.

DeFries, R. S., Foley, J. A., and Asner, G. P.: Land-use choices: balancing human needs and ecosystem function, Front. Ecol. Environ., 2, 249-257, 2004.

De Goede, R. G. M. and Brussaard, L.: Soil zoology: an indispensable component of integrated ecosystem studies, Eur. J. Soil Biol., 38, 1-6, 2002.

Dudley, N., Baldock, D., Nasi, R., and Stolton, S.: Measuring biodiversity and sustainable management in forests and agricultural landscapes, Philos. T. Roy. Soc. B., 360, 457-470, 2005.

Duelli, P. and Obrist, M. K.: Biodiversity indicators: the choice of values and measures, Agr. Ecosyst. Environ., 98, 87-98, 2003.

Eisenbeis, G. and Wichard, W.: Atlas on the Biology of Soil Arthropods, Springer, Berlin, Heidelberg, New York, 437 pp., 1987.

Faber, J. H. and Verhoef, H. A.: Functional differences between closely related soil arthropods with respect to decomposition and nitrogen mobilization in a pine forest, Soil Biol. Biochem., 23, 15-23, 1991.

Gardi, C., Menta, C., and Leoni, A.: Evaluation of environmental impact of agricultural management practices using soil microarthropods, Fresen, Environ. Bull., 17, 1165-1169, 2008.

Gomez, M. A. and Sagardoy, M. A.: Influence of glyphosate herbicide on the microflora and mesofauna of a sandy soil in a semiarid region, Rev. Latin Amer. Microbiol., 27, 351-357, 1985.

Hammer, Ø., Harper, D. A. T., and Ryan, P. D.: PAST: Paleontological Statistics Software Package for Education and Data Analysis, Palaeontologia Electron., 4, 9 pp., 2001.

Harper, D. A. T. (Ed.): Numerical Palaeobiology: Computer-based Modelling and Analysis of Fossils and their Distributions, Chichester, New York, Weinheim, Brisbane, Singapore, Toronto: John Wiley \& Sons ISBN: 978-0-471-97405-5, 478 pp., 1999. 
Heisler, C.: Influence of texture damage by mechanical loads on species diversity of springtails in conventional tillaged arable land (Collembola), Entomol. Gen., 16, 39-52, 1991.

Herzog, F.: Agri-environmental schemes as landscape experiments, Agr. Ecosyst. Environ., 108, 175-177, 2005.

Hole, D. G., Perkins, A. J, Wilson, J. D., Alexander, I. H., Grice, P. V., and Evans, A. D.: Does organic farming benefit biodiversity?, Biol. Conserv., 122, 113-130, 2005.

Kardol, P., Reynolds, W. N., Norby, R. J., and Classen, A. T.: Climate change effects on soil microarthropod abundance and community structure, Appl. Soil Ecol., 47, 37-44, 2011.

Krebs, C. J.: Ecological Methodology, 1st Edn., Addison-Welsey, 654 pp., 1989.

Kromp, B.: Carabid beetles (Coleoptera, Carabidae) as bioindicators in biological and conventional farming in Austrian potato fields, Biol. Fert. Soils, 9, 182-187, 1990.

Landi, S., d'Errico, G., Gagnarli, E., Barzanti, G. P., Cito, A., Papini, R., Simoni, S., and Roversi, P. F.: Evaluation of different agronomic managements on rice mesofauna: a case study in Piedmont (North Italy), (Poster), EGU General Assembly, 27 April-2 May 2014, Wien, Austria, 2014.

Lavelle, P.: Ecological challenges for soil science, Soil Sc., 165, 73-86, 2000.

Lavelle, P., Decaens, T., Aubert, M., Barot, S., Blouin, M., Bureau, F., Margerie, P., Mora, P., and Rossi J. P.: Soil invertebrates and ecosystem services, Eur. J. Soil Biol., 42, 3-15, 2006.

Liebig, M. A. and Doran, J. W.: Impact of organic production practices on soil quality indicators, J. Environ. Qual., 28, 1601-1609, 1999.

Maraun, M. and Scheu, S.: The structure of oribatid mite communities (Acari, Oribatida): patterns, mechanisms and implications for future research, Ecography, 23, 374-383, 2000.

Mazzoncini, M., Canali, S., Giovannetti, M., Castagnoli, M., Tittarelli, F., Antichi, D., Nannelli, R., Cristiani, C., and Bàrberi, P.: Comparison of organic and conven-tional stockless arable systems: a multidisciplinary approach to soil quality evaluation, Appl. Soil Ecol., 44, 124-132, 2010.

Menta, C., Leoni, A., Bardini, M., Gardi, C., and Gatti, F.: Nematode and microarthropod communities: comparative use of soil quality bioindicators in covered dump and natural soils, Environ. Bioind., 3, 35-46, 2008.

Menta, C., Leoni, A., Gardi, C., and Conti, F. D.: Are grasslands impor-tant habitats for soil microarthropod conservation?, Biodivers. Conserv., 20, 1073-1087, 2011.

Menta C.: Soil Fauna Diversity - Function, Soil Degradation, Biological Indices, Soil Restoration, in: Agricultural and Biological Sciences "Biodiversity Conservation and Utilization in a Diverse World”, Gbolagade Akeem Lameed, ISBN 978-953-51-0719-4, 2012.

Miani, N., Skert, N., and Grahonja, R.: Biomonitoraggio sperimentale dell'inquinamento dei suoli agricoli della provincia di trieste tramite il metodo QBS (Report), available at: http://www.tecpuntobio.it/Documenti/qbsinfvg.pdf (last access: 27 May 2008), 2005.

Narula, A., Vats, L. K., and Handa, S.: Collembolans and mites of deciduous forest stand, Ind. J. Forestry, 21, 147-149, 1996.

Paoletti, M., Favretto, M., Stinner, B., Purrington, F., and Bater, J.: Invertebrates as bioindicators of soil use, Agr. Ecosyst. Environ., 34, 341-362, 1991.
Parisi, V.: La qualità biologica del suolo. Un metodo basato sui microartropodi, Acta Naturalia de l'Ateneo Parmense, 37, 97-106, 2001.

Parisi, V., Menta, C., Gardi, C., Jacomini, C., and Mozzanica, E.: Microarthropod communities as a tool to assess soil quality and biodiversity: a new approach in Italy, Agr. Ecosyst. Environ., 105, 323-333, 2005.

Pimentel, D., Hepperly, P., Hanson, J., Siedel, R., and Douds, D.: Environmental, Energetic, and Economic Comparisons of Organic and Conventional Farming Systems, BioScience, 55, 573 582, 2005.

Reddersen, J.: The arthropod fauna of organic versus conventional cereal fields in Denmark, Biol. Agric. Hortic., 15, 61-71, 1997.

Reganold, J. P., Glover, J. D, Andrews, P. K., and Hinman, H. R.: Sustainability of three apple production systems, Nature, 410, 926-930, 2001.

Renaud, A., Poinsot-Balaguer, N., Cortet, J., and Le Petit, J.: Influence of four soil maintenance practices on Collembola communities in a Mediterranean vineyard, Pedobiologia, 48, 623-630, 2004.

Ruf, A., Kuzyakov, Y., and Lopatovskaya, O.: Carbon fluxes in soil food webs of increasing complexity revealed by ${ }^{14} \mathrm{C}$ labelling and ${ }^{13} \mathrm{C}$ natural abundance, Soil Biol. Biochem., 38, 2390-2400, 2006.

Scalercio, S., Belfiore, T., Noce, M. E., Vizzarri, V., and Iannotta, N.: The impact of compounds allowed in organic farming on the above-ground arthropods of the olive ecosystem, B. Insectol., 62, 137-141, 2009.

Schaefer, M.: Interspecific interactions in the soil community, Acta Zoologica Fennica, 196, 101-106, 1995.

Sequi, P. and De Nobili, M.: Carbonio organico, in: Metodi di Analisi Chimica del Suolo, edited by: Angeli, F., Ministero per le Politiche Agricole e Forestali, Osservatorio Nazionale Pedologico e per la Qualità del Suolo, VII.1, 1-13, 2000.

Spratt, D. M.: Endoparasite control strategies: implications for biodiversity of native fauna, Int. J. Parasitol., 27, 173-180, 1997.

SPSS Inc.: SPSS ver. 13.0 Advanced Model, SPSS Inc., Chicago, Illinois, 2004.

Todd, J. H., Malone, L. A., Benge, J., Poulton, J., Barraclough, E. I., and Wohlers, M. W.: Relationships between management practices and ground-active invertebrate biodiversity in New Zealand kiwifruit orchards, Agr. Forest Entomol., doi:10.1111/afe.12121, online first, 2015.

USDA: Soil Survey Division Staff, Soil survey manual, USDA Handbook No. 18, US Govt. Printing Office, Washington, D.C., 1993.

van Bruggen, A. H. C. and Semenov, A. M.: In search of biological indicators for soil health and disease suppression, Appl. Soil Ecol., 15, 13-24, 2000.

van Diepeningen, A. D., de Vos, O. J., Korthals, G. W., and van Bruggen, A. H. C.: Effects of organic versus conventional management on chemical and biological parameters in agricultural soils, Appl. Soil Ecol., 31, 120-135, 2006.

van Straalen, N. M.: Evaluation of bioindicator systems derived from soil arthropod communities, Appl. Soil Ecol., 9, 429-437, 1998. 
Wardle, D. A., Bardgett, R. D., Klironomos, J. N., Setälä, H., van der Putten, W. H., and Wall, D. H.: Ecological linkages between aboveground and belowground biota, Science, 304, 1629-1633, 2004.
Yan, S., Singh, A. N., Fu, S., Liao, C., Wang, S., Li, Y., Cui, Y., and $\mathrm{Hu}, \mathrm{L}$.: A soil fauna index for assessing soil quality, Soil Biol. Biochem., 47, 158-165, 2012. 